\title{
PERANAN KEARIFAN LOKAL PERMAINAN TRADISIONAL DALAM PENDIDIKAN
}

\author{
Oleh : \\ I Kadek Marsiana Putra, Kadek Aria Prima Dewi PF ${ }^{1}$
}

\begin{abstract}
ABSTRAK
Permainan tradisional yang semakin hari semakin hilang di telan perkembangan jaman, sesungguhnya menyimpan sebuah keunikan, kesenian dan manfaat yang lebih besar seperti kerja sama tim, olahraga, terkadang juga membantu meningkatkan daya otak. Berbeda dengan permainan anak jaman sekarang yang hanya duduk diam memainkan permainan dalam layar monitor dan sebagainya.Secara tidak langsung anak-anak akan dirangsang kreatifitas, ketangkasan, jiwa kepemimpinan, kecerdasan, dan keluasan wawasannya melalui permainan tradisional. Namun sayangnya seiring kemajuan jaman, permainan yang bermanfaat bagi anak ini mulai ditinggalkan bahkan dilupakan.Anak-anak terlena oleh televisi dan video game yang ternyata banyak memberi dampak negatif bagi anak-anak, baik dari segi kesehatan, psikologis maupun penurunan konsentrasi dan semangat belajar.Menguatnya arus globalisasi di Indonesia yang membawa pola kehidupan dan hiburan baru, mau tidak mau, memberikan dampak tertentu terhadap kehidupan sosial budaya masyarakat. Termasuk di dalamnya berbagai macam permainan tradisional anak.
\end{abstract}

\begin{abstract}
Traditional games are increasingly lost in the wake of the times, actually save a uniqueness, art and greater benefits such as teamwork, sports, sometimes also help improve brain power. Unlike the children's games today that just sit still playing the game on the screen and so forth. Indirectly children will be stimulated creativity, agility, leadership, intelligence, and breadth of insight through the traditional game. But unfortunately as the times progressed, the game is beneficial for this child began to be abandoned even forgotten. Children are lulled by television and video games that turn out to have a negative impact on children, both in terms of health, psychological and decreased concentration and spirit of learning. The strengthening of globalization in Indonesia that bring new life and entertainment pattern will inevitably give a certain impact to the socio-cultural life of the community. Includes a wide range of traditional children's games
\end{abstract}

\section{PENDAHULUAN}

Belajar adalah suatu proses belajar yang kompleks yang terjadi pada diri setiap orang yang hidup. Proses belajar itu terjadi karena adanya interaksi antara manusia dengan lingkunganya.oleh karena itu belajar dapat terjadi kapan saja dan dimana saja.salah satu tanda bahwa seseorang itu telah belajar adalah adanya perubahan tingkah laku pada diri orang tersebutyang mungkin terjadi oleh perubahan

${ }^{1}$ Mahasiswa Program Studi Magister Sastra Agama Dan Pendidikan Bahasa Bali IHDN DENPASAR 
pada pengetahuan,keterampilan atau sikap. Apabila proses belajar itu di selenggarakan secara formal di sekolah-sekolah. Tidak lai ini dimaksudkan untuk mengarahkan perubahan pada diri siswa. Baik dalam aspek pengetahuan, keterampilan maupun sikap.selama proses belajar tersebut di pengaruhi oleh lingkungan yang antar alain yaitu:trdiri atas muted, guru, dan staf sekolah lainnya.serta bahan maeri lainyaperkembangan ilmu pengetahuan dan teknologi semakin mendorong pembaharuan dalam prosespembelajaran

Keberhasilan sebuah pembelajaran tidak hanya ditentukan oleh tingginya pendidikan seorang pendidik. Tersedianya sarana dan prasarana pendidikan merupakan salah satu faktor penunjang berhasilnya pembelajaran. Keterbatasan sarana dan prasarana pembelajaran dapat diatasi dengan memanfaatkan yang ada di lingkungan sekitar. Permainan tradisional daerah juga memiliki potensi besar untuk dimanfaatkan dalam pembelajaran Pembelajaran di Sekolah diharapkan tidak hanya bersifat teoritik tetapi juga dapat mengenalkan media pembelajaran dengan menggunakan permainan tradisonal, karena dalam permaianan tradisional mempunyai nilai nilai pengetahuan yang seharusnya dilestarikan oleh guru, sekalipun pada kenyataannya permainan tradisional sedikit demi sedikit ditinggalkan, permainan tradisional merupakan ciri suatu bangsa, dan hasil suatu peradaban. Bangsa mana yang tidak bangga pada permainan budaya. Karenanya, menggali, melestarikan dan mengembangkan permainan tradisional adalah suatu hal yang tidak dapat dihindari. Selain telah menjadi ciri suatu bangsa, permaian tradisional adalah salah satu bagian terbesar dalam suatu kerangka yang lebih luas yaitu kebudayaan. Permainan tempo dulu sebenarnya sangat baik untuk melatih fisik dan mentalanak.

Banyaknya kegunaan permaianan bagi proses pembelajaran perlu adanya pelestarian terhadap keutuhan permaianan tersebut.
Mengenal permainan tradisional bermain congklak, egrang, balap karung, bola bekel dan lain-lain di masa muda, akan mengantarkan mereka pada permainan yang bermamfaat dalam kegiatan belajar untuk meraih prestasi di masa yang akan datang. Tanpa mengenalnya di masa muda, sulit bagi anak-anak untuk menerima hal yang sama yang dahulu mereka mainkan bahkan yang pernah dimainkan pula oleh ayah, ibu, dan kakek-neneknya. Operasional pelaksanaan pembelajaran dengan menggunakan permainan tradisional dapat dilakukan dengan memanfaatkan benda-benda yang ada di sekitar. misalnya dalam permainan gasingan yang terbuat dari kayu, layangan, yoyo, parasut dan-lain-lain. Bagi anak permainan dapat dijadikan kegiatan yang serius, tetapi mengasyikan. Melalui permainan, berbagai pekerjaannya dapat terwujud dan permainan dapat dipilih oleh anak karena menyenangkan bukan untuk memperoleh hadiah atas pujian.Permainan tradisional juga dapat membantu fisik bisa lebih sehat karena disana kita bisa beraktifitas (mengeluarkan keringat) dengan demikian dapat di tarik kesimpulan media adalah bagian yang tak terpisahkan dari proses belajar mengajardemi tercapainya media pendidikan pada umumnya dan tujuan pembelajarab pada khususnya.

\subsection{Pendidikan Karakter}

Secara harfiah karakter artinya "kualitas mental atau moral, kekuatan moral, nama atau reputasi" (Hornby dan Pornwell, 1972: 49). Dalam kamus psikologidinyatakan bahwa karakter adalah kepribadian ditinjau dari titik tolak etis atau moral, misalnya kejujuran seseorang yang biasanya mempunyai kaitan dengan sifat-sifat yang relative tetap (dali Gulo, 1982: 29). Dengan demikian dapat disimpulkan bahwa karakter merupakan nilai-nilai perilaku manusia yang berhubungan dengan TuhanYang Maha Esa, diri sendiri, sesama manusia, lingkungan dan kebangsaan yang terwujud dalam pikiran, sikap, perasaan, perkataan, dan 
perbuatan berdasarkan norma-norma agama, hokum, tata krama, budaya, dan adat istiadat. Menurut Thomas Lickona (1991), pendidikan karakter adalah pendidikan budi pekerti, yaitu yang melibatkan aspek pengetahuan (cognitive), perasaan ( feeling), dan tindakan (action), tanpa ketiga aspek ini, maka pendidikan karakter tidak akan efektif. Kemendiknas (2010), pendidikan karakter merupakan upaya-upaya yang dirancang dan dilaksanakan secara sistematis untuk membantu peserta didik memahami nilai-nilai perilaku manusia yang berhubungan dengan Tuhan Yang Maha Esa, diri sendiri, sesama manusia, lingkungan, dan kebangsaan yang terwujud dalam pikiran, sikap, perasaan, perkataan, dan perbuatan berdasarkan norma-norma agama, hokum, tata krama, budaya, dan adat istiadat. Dalam pendidikan karakter di sekolah, semua komponen ( stakeholders) harus dilibatkan, termasuk komponen-komponen pendidikan itu sendiri, yaitu isi kurikulum, proses pembelajaran dan penilaian, kualitas hubungan, penanganan atau pengelolaan mata pelajaran, pengelolaan sekolah, pelaksanaan aktivitas, pemberdayaan sarana prasarana, pembiayaan, dan etos kerja seluruh warga dan lingkungan sekolah. Pendidikan karakter dapat diintegrasikan dalam pembelajaran pada setiap mata pelajaran. Materi pembelajaran yang berkaitan dengan norma atau nilai-nilai pada setiap mata pelajaran perlu dikembangkan, dieksplisitkan, dikaitkan dengan konteks kehidupan seharihari. Dengan demikian pembelajaran nilai-nilai karakter tidak hanya pada tataran kognitif, tetapi menyentuh pada internalisasi dan pengamalan nyata dalam kehidupan peserta didik seharihari di masyarakat. Pendidikan karakter bertujuan untuk meningkatkan mutu penyelenggaraan dan hasil pendidikan di sekolah yang mengarah pada pencapaian pembentukan karakter dan akhlak mulia peserta didik secara utuh, terpadu, dan seimbang, sesuai standar kompetensi kelulusan. Melalui pendidikan karakter diharapkan peserta didik mampu secara mandiri meningkatkan dan menggunakan pengetahuannya, mengkaji dan menginternalisasi serta mempersonalisasinilai-nilaikarakterdan akhlak mulia sehingga terwujud dalam perilaku seharihari. Melalui program ini diharapkan setiap lulusan memiliki keimanan dan ketaqwaan kepada Tuhan Yang Maha Esa, berakhlak mulia, berkarakter mulia, kompetensi akademik yang utuh dan terpadu, sekaligus memiliki kepribadian yang baik sesuai norma-norma dan budaya Indonesia. Pada tataran yang lebih luas, pendidikan karakter nantinya diharapkan menjadi budaya sekolah." Character dermines someone's private thoughts and someone'sactions done. Good character is the inward motivation to do what is right, according to the highest standard of behavior, in every situation"(Hill, 2005). Memiliki arti pendidikan karakter mengajarkan kebiasaan cara berpikir dan perilaku yang membantu individu untuk hidup dan bekerja bersama sebagai keluarga, masyarakat, dan bernegara dan membantu mereka untuk membuat keputusan yang dapat dipertanggungjawabkan. Karakter yang menjadi acuan seperti yang terdapat dalamThe Six Pillars of Character yang dikeluarkan olehCharacetr Counts! Coalition (a project of The joseph Institute of Ethics) yaitu enam jenis karakteryang dimaksud adalah sebagai berikut: 1)Trustworthiness, bentuk karakter yang membuat sesorang menjadi berintegritas, jujur, dan loyal. 2) Fairness , bentuk karakter yang membuatseseorangmemiliki pemikiranterbuka serta tidak suka memanfaatkan orang lain. 3) Caring, bentuk karakter yang membuat seseorang memiliki sikap peduli dan perhatian terhadap orang lain mauupun kondisi sosial lingkungan sekitar. 4) Respect, bentuk karakter yang membuat seseorang selalu menghargai dan menghormati orang lain. 5) Citizenship , bentuk karakter yang membuat seseorang sadar hokum dan peraturan serta peduli terhadap lingkungan alam. 6) 
Responsibility, bentuk karakter yang membuat seseorang bertanggung jawab, disiplin, dan selalu melakukan sesuatu dengan sebaik mungkin (Hill, 2005). Dengan pendidikan karakter yang diterapkan secara sistematis dan berkelanjutan, seorang anak akan menjadi cerdas emosinya. Kecerdasan emosi ini adalah bekal penting dalam mempersiapkan anak menyongsong masa depan, karena seseorang akan lebih mudah dan berhasil menghadapi segala macam tantangan kehidupan, termasuk tantangan untuk berhasil secara akademis.

\section{KERANGKA KONSEPTUAL DAN TEORITIK}

Secara konsepsual kearifan lokal merupakan bagian dari kebudayaan. Haryati Subadio (1986:18-19) mengatakan kearifan lokal (local genius) secara keseluruhan meliputi, bahkan mungkin dapat dianggap sama dengan cultural identity yang dapat diartikan dengan identitas atau keperibadian budaya suatu bangsa. Sementara itu konsep kearifan lokal (local genius) yang dikemukakan oleh Quaritch Wales (dalamAstra,2004:112) adalah "....the sum of cultural characteristic which the vast majority of people have in common as a result of their experiences in early life" (keseluruhan ciri-ciri kebudayaan yang dimiliki oleh suatu masyarakat/bangsa sebagai hasil pengalaman mereka di masa lampau).

Dalam pandangan Mundardjito (1986:41) bahwa kearifan lokal terbina secara kumulatif, terbentuk secara evolusioner, bersifat tidak abadi, dapat menyusut, dan tidak selamanya tampak jelas secara lahiriah. Sementara Poespowardojo (dalam Astra, 2004:114) secara tegas menyebutkan bahwa sifat-sifat hakiki kearifan lokal adalah: 1) mampu bertahan terhadap budaya luar; 2) memiliki kemampuan mengakomodasi unsur-unsur budaya luar; 3 ) mempunyai kemampuan mengintegrasi unsurunsur budaya luar ke dalam kebudayaan asli; 4) mampu mengendalikan; dan 5) mampu memberikan arah pada perkembangan budaya. Atas dasar itu kearifan lokal dapat dimaknai sebagai kebijakan manusia dan komunitas dengan bersandar pada filosofi, nilai-nilai, etika, cara-cara, dan perilaku yang melembaga secara tradisional mengelola berbagai sumber daya alam, sumber daya hayati, sumber daya manusia, dan sumber daya budaya untuk kelestarian sumber kaya tersebut bagi kelangsungan hidupberkelanjutan

Menurut teori behavioristik, belajar adalah perubahan tingkah laku sebagai akibat adanya interaksi antara stimulus (rangsangan) dan respon (tanggapan). Dengan kata lain, belajar merupakan bentuk perubahan yang dialami siswa dalam hal kemampuannya untuk bertingkah laku dengan cara yang baru sebagai hasil interaksi antara stimulus dan respon. Seseorang dianggap telah belajar sesuatu jika ia dapat menunjukkan perubahan pada tingkah lakunya.

Menurut teori ini hal yang paling penting adalah input (masukan) yang berupa stimulus dan output (keluaran) yang berupa respon. Menurut toeri ini, apa yang tejadi diantara stimulus dan respon dianggap tidak penting diperhatikan karena tidak dapat diamati dan tidak dapat diukur.Yang dapat diamati hanyalah stimulus dan respon. Oleh sebab itu, apa saja yang diberikan guru (stimulus) dan apa yang dihasilkan siswa (respon), semuanya harus dapat diamati dan diukur. Teori ini lebih mengutamakan pengukuran, sebab pengukuran merupakan suatu hal yang penting untuk melihat terjadinya perubahan tungkah laku tersebut. Faktor lain yang juga dianggap penting adalah faktor penguatan. Penguatan adalah apa saja yang dapat memperkuat timbulnya respon. Bila penguatan diitambahkan maka respon akan semakin kuat. Begitu juga bila penguatan dikurangi maka responpun akan dikuatkan. Jadi, penguatan merupakan suatu bentuk stimulus yang penting diberikan (ditambahkan) atau dihilangkan (dikurangi) untuk memungkinkan terjadinya respon. 
Tokoh-tokoh aliran behavioristik diantaranya:

1. Thorndike

Menurut thorndike, belajar merupakan proses interaksi antara stimulus dan respon. Dan perubahan tingkah laku merupakan akibat dari kegiatan belajar yang berwujud konkrit yaitu dapat diamati atau berwujud tidak konkrit yaitu tidak dapat diamati. Teori ini juga disebut sebagai aliran koneksionisme (connectinism).

2. Watson

Menurut Watson, belajar merpakan proses interaksi antara stimulus dan respon, namun stimulus dan respon yang dimaksud harus berbentuk tingkah laku yang dapat diamati dan dapat diukur. Dengan kata lain, meskipun ia mengakui adanya perubahan-perubahan mental dalam diri seseorang selama proses belajar, namun ia menganggap hal-hal tersebut sebagai faktor yang tak perlu diperhitungkan. Ia tetap mengakui bahwa perubahanperubahan mental dalam bentuk benak siswa itu penting, namun semua itu tidak dapat menjelaskan apakah seseorang telah belajar atau belum karena tidak dapat diamati.

\section{ClarkHull}

Clark Hull juga menggunakan variable hubangan antara stimulus dan respon untuk menjelaskan pengertian tentang belajar. Namun ia sangat terpengaruh oleh teori evolusi Charles Darwin. Baginya, seperti teori evolusi, semua fungsi tingkah laku bermanfaat terutama untuk menjaga kelangsungan hidup manusia. Oleh sebab itu, teori ini mengatakan bahwa kebutuhan biologis dan pemuasan kebutuhan biologis adalah penting dan menempati posisi sentral dalam seluruh bagian manusia, sehingga stimulus dalam belajarpun hampir selalu dikaitkan dengan kebutuhan biologis, walaupun respon yang akan muncul mungkin dapat bermacam-macam bentuknya.

Dalam megoak-goakan arahannya menuju ke teori afektif dimana ranah afektif adalah ranah yang berkaitan dengan sikap dan nilai. Ranah afektif mencakup watak perilaku seperti perasaan, minat, sikap, emosi, dan nilai. Beberapa pakar mengatakan bahwa sikap seseorang dapat diramalkan perubahannya bila seseorang telah memiliki kekuasaan kognitif tingkat tinggi. Ciri-ciri hasil belajar afektif akan tampak pada peserta didik dalam berbagai tingkahlaku.

Ranah afektif menjadi lebih rinci lagi ke dalam limajenjang, yaitu:

1. Receiving atau attending ( menerima atua memperhatikan)

2 Responding(menanggapi)mengandung arti "adanya partisipasi aktif"

3. Valuing (menilai atau menghargai)

4. Organization (mengatur atau mengorganisasikan)

5. Characterization by evalue or calue complex (karakterisasi dengan suatu nilai) Jiikadihubungkan dengan megoak-goakan dapat dari segi kekompakan permainan bisa kita tinjau dari segi afektifnya, dimanan kerap berhubungan dalam sikap.Dalam permainan megoak-goakan membentuk 1 kelompok besar dimana tersusun dari anak yang berbadan tinggi dan diikuti oleh anakyang berbadan lebih kecil, sehinggajiika dikaitkan dalam kelompk belajar mengajarkan untuk anak didik tidak membedabedakan anggota kelompok dan menjaga satu kesatuan dalam kelompok tersebut. Dalam permainan megoak-goakan ada yang berperan sebagai penculik untuk mengganggu kelompok tersebut dimana anggota kelompok yang paling belakang akan dijadikan mangsa, disana tumbuhlah sikap Receiving, responding, valuing, organization, Characterization by evalue or calue complexyang merupakan komponen-komponen dalam sikap apektif. 
III. PERANAN KEARIFAN LOKAL PERMAINAN TRADISIONAL DALAM PENDIDIKAN

Kearifan lokal tidak terlepas dari sebuah media. Media berasal dari bahasa latin yang medius yng secara harfiah berarti "tengah",perantara"atau dalam bahasa arab media adalah pengantar atau pengantar pesan dari pengirim kepada penerima pesan Gerlach \& Eli (1971) mengatakan apabila media dipahami secara garis besar adalah manusia,materi,atau kejadian yang membangun kondisi yang membuat siswa memperoleh pengetahuan, keterampilan atau sikap . dalam pengertian ini guru,buku teks, d lingkungan sekolah merupakan media,secara lebih khusus pengertian media dalam proses belajar mengajar cenderung diartikan sebagai alat-alat grafis, photo grafish,atau elektronis untuk menangkap, memproses atau menyusun kembali informasi visual dan verbal.

Batasan lain telah pula di kemukakan oleh para ahli sebagian diantaranya akan di berikan sebagai berikut.AECT(association of education and communication tenologi 1977) memberi batasan tentang media sebagai segala bentuk dan saluran yang digunakan untuk menyampaikan pessn dan informasi. Disamping sebagai system penyampai atau pengantar, mediayang sering dig anti dengan kata mediator menurut fleming(1987:234)adlah penyebap atau alat yang turut ikut campur tangan dlam 2 pihak untuk mendamaikannya.dengan istilah mediator media menunjukkan fungsi da peranannya, yaitu mengatur hubungan yang efektif di kedua pihak dua pihak utamadalam proses belajar-siswa dan isi pelajaran.selain itu mediator dapat pula mencerminkan penertian bahwa setiap system pembelajaran yang melakukan mediasi,mulai dari guru sampai dengan peralatan yang paling cangngih dapat di sebu dengan media ringkasnymedia adlah alat yang menyampaikan atu mengantarkan pesan-pesan pembelajaran Heinich dan kawankawan (1982) mengemukakan medium sebagai media atau perantar yang menghaturkan informasi antara sumber dan penerima jadi tv,film radio, dan audio visual lainnya apabila media itu membawa informasi yang bersedia menerima.

Secara definisi kata media berasal dari berasa latin medius yang secara harfiah "tengah", perantara atau pengantar. Dalam bahasa yang lain media adalah pengantar pesan dari pengirim kepada penerima. Association for education and commonication technology (AECT), mengartikan kata media sebagai segala bentuk dan saluran yang dipergunakan untuk menyampaikan pesan atau informasi. National education association (NEA) mendefinisikan media sebagai segala benda yang dapat dimanipulasi, dilihat, didengar, dibaca dan dibicarakan beserta instrumen yang dipergunakan untuk kegiatan tersebut. Sementara menurut Heinich, menyatakan:
A medium (plural media) is a channel of commonication, derived from the latin word meaning "between" the term refers to anything that carries information, diagrams, printed materials, computers, and instructors. These are considered instructional media when the carry messages with in instructional purpose. The purpose of media is to facilitate commonication.

Maksud dari pernyataan tersebut bahwa media sebagai menyalur informasi kepada yang menerima, dalam bahasa latin media adalah "between" yang sama halnya dengan "anything that carries information between a source and receiver", yaitu penyampai bahwa media merupakan pembawa informasi dari sumber ke penerima. Pembawa informasi ini dapat berupa manusia, termasuk dalam media ini film, televisi diagram. Demikian juga permainan tradisional yang dapat dijadikan sebagai media dalam pembelajaran.Dalam kegiatan proses pembelajaran kehadiran media mempunyai arti yang cukup penting. Karena dalam kegiatan 
tersebut ketidakjelasan bahan yang disampaikan dapat dibantu dengan menghadirkan media sebagai perantara. Media merupakan alat bantu apa saja termasuk mainan tradisional yang dapat dijadikan sebagai penyalur pesan guna mencapai tujuan pembelajaran”. Media pembelajaran harus meningkatkan motivasi siswa dan merangsang siswa mengingat yang sudah dipelajari dan memberikan rangsangan baru. Media yang baik juga dapat mengaktifkan dalam memberikan tanggapan, merangsang untuk belajar penuh semangat, dan mendorong siswa lebih giat dalam belajar.

\subsection{Pengertian PermainanTradisional}

Permainan tradisonal merupakan simbolisasi dari pengetahuan yang turun temurun dan mempunyai bermacam-macam fungsi atau pesan di baliknya, di mana pada prinsipnya permainan anak tetap merupakan permainan anak. Dengan demikian bentuk atau wujudnya tetap menyenangkan dan menggembirakan anak karena tujuannya sebagai media permainan. Aktivitas permainan yang dapat mengembangkan aspek-aspek psikologis anak dapat dijadikan sarana belajar sebagai persiapan menuju dunia orang dewasa. Permaianan digunakan sebagai istilah luas yang mencakup jangkauan kegiatan dan prilaku yang luas serta mungkin bertindak sebagai ragam tujuan yang sesuai dengan usia anak. Menurut Pellegrini dalam Naville Bennet bahwa permainan didefinisikan menurut tiga matra sebagai berikut: (1) Permainan sebagai kecendrungan, (2) Permainan sebagai konteks, dan (3) Permainan sebagai prilaku yang dapat diamati.

Menurut Mulyadi bermain secara umum sering dikaitkan dengan kegiatan anak-anak yang dilakukan secara spontan yang terdapat lima pengertian bermain; (1) sesuatu yang menyenangkan dan memiliki nilai intrinsik pada anak (2) tidak memiliki tujuan ekstrinsik, motivasinya lebih bersifat intrinsik (3) bersifat spontan dan sukarela, tidak ada unsur keterpaksaan dan bebas dipilih oleh anak serta melibatkan peran aktif keikutsertaan anak, dan (4) memiliki hubungan sistematik yang khusus dengan seuatu yang bukan bermain, seperti kreativitas, pemecahan masalah, belajar bahasa, perkembangan sosial.

Permainan tradisonal merupakan simbolisasi dari pengetahuan yang turun temurun dan mempunyai bermacam-macam fungsi atau pesan di baliknya, di mana pada prinsipnya permainan anak tetap merupakan permainan anak.Dengan demikian bentuk atau wujudnya tetap menyenangkan dan menggembirakan anak karena tujuannya sebagai media permainan.Aktivitas permainan yang dapat mengembangkan aspek-aspek psikologis anak dapat dijadikan sarana belajar sebagai persiapan menuju dunia orang dewasa.

Permainan tradisional merupakan warisan antar generasi yang mempunyai makna simbolis di balik gerakan, ucapan, maupun alat-alat yang digunakan.Pesan-pesan tersebutbermanfaat bagi perkembangan kognitif, emosi dan sosial anak sebagai persiapan atau sarana belajar menuju kehidupan di masa dewasa.Pesatnya perkembangan permainan elektronik membuat posisi permainan tradisional semakin tergerus dan nyaris tak dikenal. Memperhatikan hal tersebut perlu usaha-usaha dari berbagai pihak untuk mengkaji dan melestarikan keberadaannya melalui pembelajaran ulang pada generasi sekarang melalui proses modifikasi yang disesuaikan dengan kondisi sekarang (Elly Fajarwat, 2008: 2).

Permaianan digunakan sebagai istilah luas yang mencakup jangkauan kegiatan dan prilaku yang luas serta mungkin bertindak sebagai ragam tujuan yang sesuai dengan usia anak. Menurut Pellegrini (1991: 241) dalam Naville Bennet (1998: 5-6) bahwa permainan didefinisikanmenuruttiga matra sebagai berikut; (1) permainan sebagai kecendrungan, (2) permainan sebagai konteks, dan (3) permainan sebagai prilaku yang dapat diamati.Permainan tidak lepas dari pada adanya kegiatan bermain 
anak, sehingga istilah bermain dapat digunakan secara bebas, yang paling tepat adalah setiap kegiatan yang dilakukan untuk kesenangan yang ditimbulkan, bermain dilakukan secara suka rela oleh anak tanpa ada pemaksaan atau tekanan dari luar. Menurut Elizabeth B, H (2006: 320), secara garis besar dapat dibagi menjadi dua kategori yaitu aktif dan pasif .

\subsection{Peran Permainan Tradisional}

Didalam masyarakat peran penting dalam permainan tradisional, perlu kita kembangkan demi ketahanan budaya bangsa, karena kita menyadari bahwa kebudayaan merupakan nilainilai luhur bagi bangsa indonesia, untuk diketahui dan dihayati tata cara kehidupannya sejak dahulu. Bangsa indonesia merupakan bangsa yang besar dalam keaneka ragaman kebudayaan didalamnya, termasuk permainan tradisional didalamnya, keanekaragaman permainan tradisional adalah karena banyaknya daerah di indonesia memiliki kearifan lokal kebudayaan masing-masing, sehingga membentuk masyarakatn melakukan aktivitas kebugaran jasmani yang berbeda satu daerah dengan yang lainnya. Permainan tradisonal memang sudah seharusnya mendapatkan perhatian khusus dan mendapatkan prioritas yang utama untuk dilindungi, dibina, dikembangkan, diberdayakan dan selanjutnya diwariskan. Hal seperti itu diperlukan agar permaina tradisional dapat memiliki ketahanan dalam menghadapi unsur budaya lain di luar kebudayaannya.

\subsection{Jenis-jenis Permainan Tradisional}

Banyak sekali macam-macam permainan tradisional di Indonesia, hampir di seluruh daerah-daerah telah mengenalnya bahkan pernah mengalami masa-masa bermain permainan tradisional ketika kecil. Permainan tradisional perlu dikembangkan lagi karena mengandung banyak unsur manfaat dan persiapan bagi anak dalam menjalani kehidupan bermasyarakat. Adapun beberapa contoh permainan tradisional akan dijelaskan secara lebih rinci sebagai berikut :

1. Galah asin atau galasin yang juga sibeut gobak sodor adalah sejenis permainan daerah asli dari Indonesia. Permainan ini adalah sebuah permainan grup yang terdiri dari dua grup, di mana masing-masing tim terdiri dari 3 - 5 orang. Inti permainannya adalah menghadang lawan agar tidak bisa lolos melewati garis ke baris terakhir secara bolak-balik, dan untuk meraih kemenangan seluruh anggota grup harus secara lengkap melakukan proses bolakbalik dalam area lapangan yang telah ditentukan.

Permainan ini biasanya dimainkan di lapangan bulu tangkis dengan acuan garisgaris yang ada atau bisa juga dengan menggunakan lapangan segi empat dengan ukuran 9 x 4 m yang dibagi menjadi 6 bagian. Garis batas dari setiap bagian biasanya diberi tanda dengan kapur. Anggota grup yang mendapat giliran untuk menjaga lapangan ini terbagi dua, yaitu anggota grup yang menjaga garis batas horisontal dan garis batas vertikal. Bagi anggota grup yang mendapatkan tugas untuk menjaga garis batas horisontal, maka mereka akan berusaha untuk menghalangi lawan mereka yang juga berusaha untuk melewati garis batas yang sudah ditentukan sebagai garis batas bebas. Bagi anggota grup yang mendapatkan tugas untuk menjaga garis batas vertikal (umumnya hanya satu orang), maka orang ini mempunyai akses untuk keseluruhan garis batas vertikal yang terletak di tengah lapangan. Permainan ini sangat mengasyikkan sekaligus sangat sulit karena setiap orang harus selalu berjaga dan berlari secepat mungkin jika diperlukan untukmeraih kemenangan.

2. Congklakadalah suatu jenis permainan tradisional yang dikenal dengan berbagai 
macam nama di seluruh indonesia. Biasanya dalam permainan, sejenis cangkang kerang digunakan sebagai biji congklak dan jika tidak ada, kadangkala digunakan juga biji-bijian dari tumbuhtumbuhan.

Di malaysia permainan ini juga lebih dikenal dengan nama congklak dan istilah ini juga dikenal di beberapa daerah di Sumatera dengan kebudayaan melayu. Di jawa, permainan ini lebih dikenal dengan nama dakon. Selain itu di lampung permainan ini lebih dikenal dengan nama dentuman lamban sedangkan di Sulawesi permainan ini lebih dikenal dengan nama mokaotan, maggaleceng, aggalacang dan nogarata. Dalam bahasa Inggris, permainan ini disebut mancala.

3. Petak Umpet permainan ini bisa dimainkan oleh minimal 2 orang, namun jika semakin banyak yang bermain maka akan menjadi semakin seru. Cara bermain cukup mudah, dimulai dengan hompimpa untuk menentukan siapa yang menjadi "kucing" (berperan sebagai pencari temantemannya yang bersembunyi). Si kucing ini nantinya akan memejamkan mata atau berbalik sambil berhitung sampai 10 , biasanya dia menghadap tembok, pohon atau apa saja supaya dia tidak melihat teman-temannya bergerak untuk bersembunyi (tempat jaga ini memiliki sebutan yang berbeda di setiap daerah, contohnya di beberapa daerah di jakarta ada yang menyebutnya inglo, di daerah lain menyebutnya bon dan ada juga yang menamai tempat itu hong). Setelah hitungan sepuluh (atau hitungan yang telah disepakati bersama, misalnya jika wilayahnya terbuka, hitungan biasanya ditambah menjadi 15 atau 20) dan setelah teman-temannya bersembunyi, mulailah si "kucing" beraksi mencari teman-temannya tersebut.

\section{Pengimplementasian Permainan Tradisional Sebagai Wahana Dalam Pendidikan Karakter Yang Menyenangkan}

Begitu pentingnya permainan tradisional dalam memberi pendidikan karakter dan memberikan nilai moral yang positif bagi pertumbuhan anak. Melalui permainan tradisional juga dapat menjadi sarana belajar untuk mengembangkan nilai EQ pada anak. Tetapi, tentu saja harus dalam pengawasan dan memberi batasan waktu yang jelas agar tidak semua waktu digunakan untuk bermain. Implementasi dari permaninan tradisional sebagai wahana pendidikan karakter yang menyenangkan dapat diaplikasikan baik di lingkungankeluarga(informal), sekolah(formal) maupun di masyarakat (nonformal). Pendidikan karakter dapat dimulai dari lingkungan yang terkecil yakni, Keluarga. Keluarga merupakan bagian dari sebuah masyarakat. Unsur-unsur yang ada dalam sebuah keluarga baik budaya, agama, ekonomi bahkan jumlah anggota keluarga sangat mempengaruhi perlakuan dan pemikiran anak khususnya ayah dan ibu. Pengaruh keluarga dalam pendidikan anak sangat besar dalam berbagai macam sisi. Keluargalah yang menyiapkan potensi pertumbuhandan pembentukankepribadian anak. Lebih jelasnya, kepribadian anak tergantung pada pemikiran dan tingkah laku kedua orang tua serta lingkungannya. Dalam hubungannya dengan pendidikan karakter, keluarga memiliki andil yang cukup besar, karena mulai darisinilah penanaman nilai-nilai moral dapat dikembangkan sehingga permasalahan kenakalan remaja dapat dihindari. Secara garis besar, pendidikan karakter bertujuan untuk membimbinganak ke arah kedewasaan supaya anak dapat memperoleh keseimbangan antara perasaan dan akal budaya serta dapat mewujudkan keseimbangan dalam perbuatannya kelak. Oleh karena itu, langkah pasti yang dapat dtempuh oleh orang tua yakni, mampu memberikan stimulus yang positif serta menyenangkan 
kepada anaknya, salah satunya melalui permainan tradisional. Pengembangan permaninan tradisional sebagai wahana pendidikakan karakter yang menyenangkan tidak begitu sulit. Perlu kesabaran serta keseriusan dari pihak orang tua. Orang tua juga dapat menyusun rancangan kegiatan yang menarik kepada anaknya. Seperti setiap akhir pekan atau pertemuan keluarga, orang tua bisa mengajak si anak untuk berekreasi serta mengajak buah hatinya untuk memainkan permainan tradisional. Disinilah peran orang tua yang paling penting yakni, dapat menjelaskan makna yang terkandung dalam permainan tersebut. Penanaman pendidikan karakter semacam ini sangat efektif, akan tetapi tetap diimbangi oleh kemauan anak tersebut, sehingga tidak terjadi kesalah pahaman atau benturan. Berikut ini rancangan kegiatan yang dapat diaplikasikan oleh orang tua, dalam memberikan pendidikan karakter melalui permainan tradisional.

Di era global saat ini, memudarnya permainan atau olahraga tradisional tidak menjadi hal yang baru lagi. Masuknya kecanggihan teknologi membawa masyarakat tradisional bangsa indonesia, menjadi lebih praktis. Kini masyrakat mengaggap permainan atau olahraga tradisional, dapat digantikan dengan game online dan fitnes center. Pergantian permainan tradisional akibat globalisasi dikarenakan kurangnya kesadaran masyarakat indonesia terhadap pentingnya melestarikan permainan lokal atau olahraga tradisional dalam kehidupan sehari-hari. Permainan tradisional memberikan dampak yang sangat positif bagi seorang anak pada usia yang dini. Perkembangan kemajuan teknologi ,informasi dan komunikasi saat ini, membuat perubahan sosial dalam masyrakat seluruh dunia. Masyarakat Indonesia termasuk yang mendapatkan dampak seperti ini juga. Memudarnya permainan Tradisional di era globalisasi termasuk perubahan sosial yang terjadi akibat dari kurangnya kesadaran masayarakat lokal melestarikan dan memberdayakan permainan tersebut dalam kehidupan sehari-hari. Ini terjadi contohnya, pada semakin berkembangnya games online lebih diminati dan disukai anak-anak zaman sekarang ketimbang permainan tradisional atau anak-anak yang zaman dahulu sering kita mainkan.

Menurut William F. Ogburn Seorang sosiologiAmerika, merupakan ilmuan pertama yang melakukan penelitian terinci menyangkut proses perubahan sosial. William F. Ogburn juga menyatakan bahwa perubahan sosial mencakup unsur-unsur kebudayaan baik material maupun non material. Ogburn berpendapat bahwa budaya material berubah lebih cepat dibandingkan dengan budaya non material yang dapat menyebabkan terjadinya cultural lag. Sedangkan Globalisasi adalah suatu proses di mana antar individu, antar kelompok, dan antar negara saling berinteraksi, bergantung, terkait, dan memengaruhi satu sama lain yang melintasi batas Negara. Dalam perkembangan kemajuan teknologi, informasi dan komunikasi keterkaitan antara perubahan sosial dan globalisasi adalah terhadap perubahan dalam budaya masyakarat lokal yang cenderung dinamis terhadap kemajuan zaman, dan menerima masuknya kemajuan teknologi dengan mudah dalam masyarakat. Dalam suatu Masyarakat yang menerima perubahan sosial cenderung akan memiliki dampak yang ditimbulkan bagi masyarakat yang menerima perubahan sosial itu sendiri. Terlebih dalam Perkembangan Teknologi Informasi sudah yang sedemikian pesatnya sangat sulit bagi kita untuk mengontrolnya. Hampir setiap detik produk Teknologi Informasi tercipta di seluruh belahan dunia. Kita patut mengapresiasi perkembangan Teknologi Informasi ini karena tentunya akan semakin membantu kehidupan manusia. Dampak positif dan negatif pemanfaatan IT sudah pasti ada dan sudah sewajarnya kita mewaspadai hal ini.

Dalam suatu Masyarakat yang menerima 
perubahan sosial cenderung akan memiliki dampak yang ditimbulkan bagi masyarakat yang menerima perubahan sosial itu sendiri. Terlebih dalam Perkembangan Teknologi Informasi sudah yang sedemikian pesatnya sangat sulit bagi kita untuk mengontrolnya. Hampir setiap detik produk Teknologi Informasi tercipta di seluruh belahan dunia.

Permainan tradisional tidak hanya sekedar permainan yang mengandung kesenangan semata. Namun permainan tradisional dapat melatih kemampuan motorik anak, sikap anak, dan juga ketrampilan anak. Serta dapat membentuk karakter anak yang luhur. Dalam menerima sikap perubahan sosial didalam masyrakat kita memang harus bersifat terbuka dan dinamis terhadapa perkembangan zaman, perkembangan dunia IT.Ada sebuah garis-garis yang harus memisahkan kebudayaan asli dengan masuknya kebudayaan luar dalam era global saat ini. Perubahan sosial akan terjadi apabila masyarakat menerima masuknya perubahan itu sendiri, maka dari itu kita perlu yang namanya kesadaran sejak dini untuk menjaga dan melstarikan kebudayaan lokal masyarakat kita sendiri, kalau bukan kita yang menjaga kebudayaan tersebut, siapa lagi dan tidak akan menutup kemungkinan memudarnya permainan tradisional, sebagai salah satu contoh penulisan diatas, dapat terjadi bila kita sendiri tidak memelihara kebudayaan kita sendiri.

Kita sebagai generasi muda sudah saatnya kita melestarikan permainan tradisional. Kita seharusnya perkenalkan dulu pada anak kita tentang permainan tradisional walaupun di zaman globalisasi saat ini. Karena pada usia dini, perkembangan anak sangat dibutuh demi perkembangan fisik dan motorik anak. Selain iti permainan tradisional sangat menguntungkan daripada permainan di zaman sekarang seperti game online. Game online sangat tidak baik bagi perkembangan anak karena akan membawa dampak negative bagi seorang anak. Tidak dipungkiri saat ini banyak orang tua yang malah membelikan anaknya barang-barang canggih. Maka dari itu, peran orang tua untuk mendampingi anaknya sangatlah penting demi masa depan seorang anak.

\section{DAFTAR PUSTAKA}

Azhar Arsyad, 2011. Media Pembelajaran Jakarta, PT RajaGrafindo Persada

http://longsani.blogspot.com/2014/07/ makalah-permanina-tradisional.html diakses pada Senin 26 pkl 11.30 wib

http://abdulkudus.staff.unisba.ac.id/files/2012/ 01/PKM-GT-2011-IPB-Irma-InovasiMedia-Pembelajaran.pdf diakses pada minggu $25 \mathrm{pkl} 13.30 \mathrm{wib}$

http://www.academia.edu/6245754/ PERMAINAN_TRADISIONAL_ SEBAGAI_WAHANA_PENDIDIKAN_ KARAKTER_YANG_MENYENANGKAN diakses pada minggu 25 pkl 10.30 wib 
